\title{
Free Radical Scavenging and In Vitro Cytotoxic Activity of Bugnay (Antidesma bunius) Leaves Extract Against A549 Human Lung Adenocarcinoma and HCT-116 Human Colorectal Cancer Cell Lines
}

\author{
Arnold Joseph O. Geronimo ${ }^{*}$, Mari Erika Joi F. Bancual ${ }^{1}$, Karl Anthony L. Ko ${ }^{1}$, Lycon Marie L. \\ Soliba $^{1}$, Jeric John C. Ildefonso ${ }^{1}$, Angelica Mae B. Soriano ${ }^{1}$, Alta Christine Marie M. Tagalog ${ }^{1}$, Nikolai \\ E. Acosta ${ }^{1}$, Vincent S. Ang ${ }^{1}$, Mariebon A. Apigo ${ }^{1}$, Dana Grace S. Buenconsejo ${ }^{1}$, Joanna Kaitlin G. Chan ${ }^{1}$, \\ Cassandra B. Gresh ${ }^{1}$, Crisel B. Santos ${ }^{1}$, Leo Emmanuel R. Buñag ${ }^{2}$, John Anthony A. Domantay ${ }^{3}$ \\ ${ }^{1}$ Medical Students, School of Medicine, Saint Louis University, Bonifacio St., Baguio City, Philippines \\ ${ }^{2}$ Faculty, Department of Pharmacology, School of Medicine, Saint Louis University, Bonifacio St., Baguio City, Philippines \\ ${ }^{3}$ Dean, School of Medicine, Saint Louis University, Bonifacio St., Baguio City, Philippines
}

\begin{abstract}
Cancer is one of the significant causes of mortality worldwide. Studies on antineoplastic drugs focused on natural products have revealed several mechanisms to inhibit cancer cells. Bugnay (Antidesma bunius) leaves showed potentials due to its activity observed against brine shrimp and breast cancer cells. However, there is still limited knowledge about its activity against other human cancer cells. This study focused on determining the phytochemical compounds in $A$. bunius leaves extract, the free radical scavenging activity of the extract using the Diphenylpicrylhydrazyl (DPPH) method, and in vitro cytotoxic activity against two cancer cell lines, namely HCT-116 human colorectal and A549 human lung adenocarcinoma cancer cell lines by using 3-(4,5-dimethylthiazol-2yl)-2,5-diphenyltetrazolium bromide (MTT) assay. The phytochemicals identified were unsaturated lactones, flavonoids, phenolics, diterpenes, saponins, tannins, carbohydrates, and reducing sugars. The extract showed significant free radical scavenging activity and a direct correlation of activity with concentration levels. It also exhibited cytotoxic activity against HCT-116 human colorectal and A549 human lung adenocarcinoma. Hence, A. bunius leaves have the potential to be a source of antioxidant and antineoplastic compounds. This warrant further isolation of the compounds for chemotherapeutic purposes.
\end{abstract}

Keywords: Antidesma bunius, Bugnay, Cancer, Cytotoxicity, Radical

\section{INTRODUCTION}

Cancer has been identified as the second leading cause of mortality worldwide; it exhibited public health concerns and burdens to the socioeconomics (Siegel, et al., 2019). Among the different kinds of cancer, lung and breast cancers are the malignancies with the highest incidences followed by colorectal globally. Due to the rise in early detection and treatment, cancer patients' life expectancy became higher (Bray, et al., 2018). However, even now, cancer deaths continuously impose a significant problem. The main culprit

Submitted: July 14, 2020

Revised: September 22, 2020

Accepted: September 22, 2020

*Corresponding author:2131443@slu.edu.ph 
has been identified, and it is the ability of tumors to become resistant to therapy through epigenetic (Zhou, et al., 2013) or genetic mechanisms (Calin, et al., 2005).

In the interest of combating cancer, recent developments have led to a rise in medicinal plants use for screening and identification of pharmacologically active and natural compounds against cancer. Some of these plant isolates, namely Vincristine, Vinblastine, and Paclitaxel, are now marketed for cancer treatments (Zulkipli, et al., 2015). These discoveries significantly contributed to developing cancer drugs and extensive studies of promising medicinal plants for cancer, which may provide less toxicity and chemoprotective potentials (Mondal, et al., 2012). Despite the various benefits acquired from natural resources, the emphasis for its utilization is still undervalued though their considerable contributions to modern pharmaceuticals and in traditional medicine are evident (Reid, et al., 2018).

Antidesma bunius is a fruit tree that is native to Southeast Asia and Northern Australia. It is common in Northern Luzon, Philippines, particularly in the Cordillera region and in Mindanao with its local Philippine name Bignay, Bugnay, or Bignai. A. bunius plant has been featured in several types of research evaluating its vast potential (Butkhup and Samappito, 2008; Kassem, et al., 2008; Mohan, et al., 2013). Notably, a study revealed its antiangiogenic property (Juan, et al., 2014), and cytotoxicity of leaves extract against brine shrimp (Micor, et al., 2005) and MCF-7 breast cancer cell line (Subarnas, et al., 2012). There are still few studies regarding the cytotoxic activity of the plant against human cancer cell lines. Hence, a more focused study in this plant's potential against other cancer cell lines is highly suggestible.

This study intended to determine the phytochemical substituents present in A. bunius leaves, to determine the free radical scavenging activity of the extract on Diphenylpicrylhydrazyl (DPPH) and to determine if there is a significant difference between the in vitro cytotoxic activity of
A. bunius leaves extract and Doxorubicin against HCT-116 human colorectal and A549 human lung adenocarcinoma cancer cells.

\section{MATERIALS AND METHODS}

\section{General Experimental Procedures}

The study utilized an experimental approach. The assessment of A. bunius was constricted to qualitative phytochemical screening, quantitative free radical inhibition analysis using DPPH method, and cytotoxicity assay under completely randomized design (CRD) with three trials per treatment using 3-(4,5-dimethylthiazol-2yl)-2,5-diphenyltetrazolium bromide (MTT) assay. All reagents used were of analytical grade.

\section{Collection and Authentication of Plant}

The plant was obtained from Alfonso Lista, Ifugao, Philippines. The parts of the plant sample (branch, leaves, flowers, and fruits) were sent for proper botanical identification and verification at the School of Natural Sciences, Saint Louis University (Baguio City, Philippines).

\section{Preparation of Extracts}

A. bunius leaves were washed with tap water followed by distilled water then chopped into fine, thin pieces. The chopped leaves were dried using the oven (Olympia, USA) at $70^{\circ} \mathrm{C}$ for $12 \mathrm{~h}$ to remove moisture. The dried leaves were crushed and pulverized using an electric blender (Kyowa 1000). Crushed leaf samples were macerated in $80 \%$ ethanol (Merck, Darmstadt, Germany) in a closed container for three days with constant agitation.

Ethanol and methanol are efficient solvents in extracting antioxidant phenolic compounds from different natural resources. However, since ethanol has a lower toxicity than methanol, it is selected as the best solvent to extract antioxidant compounds (Do, et al., 2014; Ballesteros, et al., 2014).

The obtained sample was filtered using a Whatman No. 2 filter paper and the ethanol component of the sample was allowed to evaporate. 
The crude extract was subjected to phytochemical and antioxidant determination, while the portion obtained via rotary evaporation (Laborota 4011, Heidolph) was submitted for in vitro cytotoxicity testing.

\section{Qualitative Phytochemical Analysis}

The extract's phytochemical screening was conducted at Saint Louis University (Baguio City, Philippines) by the Natural Sciences Research Unit (NSRU). The extract was analyzed for the presence of phytochemical compounds such as flavonoids, phenolic compounds, alkaloid, saponins, glycosides, phytosterols, carbohydrates, and proteins using the method of Guevara, et al. (2005).

\section{Free Radical Scavenging Analysis}

The analysis was conducted according to the standard method by Clarke, et al. (2013). Four concentrations of the A. bunius leaves extract (625, 1250,2500 , and $5000 \mu \mathrm{g} / \mathrm{mL}$ ) were prepared via serial dilution with Dimethyl sulfoxide (DMSO) (Sigma Aldrich, St. Louis, USA) as the solvent. Two hundred microliters of each concentration of the extract were added to $1.8 \mathrm{~mL}$ of DPPH (Sigma Aldrich) in ethanol (0.1 mM) (Merck) using separate test tubes. After leaving the test tubes in the dark for 30 minutes, the absorbance was measured at $518 \mathrm{~nm}$ using a VIS spectrophotometer (Labomed Inc., Los Angeles, California, USA). The same procedure was done using the different concentrations of L-Ascorbic acid (62.5, 125, $250,500 \mu \mathrm{g} / \mathrm{mL}$ ) (Sigma Aldrich, Singapore) as a control. The procedure was performed in triplicates per concentration with repeated measurements of absorbance per replicate. The DPPH radical scavenging activity was determined using the formula where Abs neg control is the absorbance of DPPH and ethanol (Clarke, et al., 2013; Barcelo, 2015):

\%Radical Scavenging Activity $=[(($ Abs neg controlAbs extract))/(Abs neg control) $] \times 100$

\section{Cell Culture}

The human lung adenocarcinoma (A549) and human colorectal (HCT-116) cancer cell lines were acquired from the American Type Culture Collection (ATTC, Manassas, USA). The cell lines were cultured in Dulbecco's Modified Eagle Medium (Gibco, New York, USA) supplemented with $10 \%$ fetal bovine serum (Gibco), 100 units/ $\mathrm{mL}$ penicillin (Gibco), $100 \mathrm{mg} / \mathrm{mL}$ streptomycin (Gibco), 0.14\% sodium bicarbonate (Gibco), and $0.1 \mathrm{mM}$ sodium pyruvate (Gibco). The cell lines were maintained in a $\mathrm{CO}_{2}$ incubator (PHCbi, Illinois, USA) with a $5 \% \mathrm{CO}_{2}$ atmosphere and $95 \%$ humidity at $37^{\circ} \mathrm{C}$.

\section{In vitro Cytotoxicity Assay}

In determining cell survival and toxicity, MTT assay was performed following the method of Mosmann (1983). In greater detail, the cells of HCT-116 human colorectal and A549 human lung adenocarcinoma cancer cell lines were seeded separately. It was seeded at $4 \times 10^{4}$ cells $/ \mathrm{mL} /$ well in sterile 96-well microtiter plates (Corning, NY, USA) and incubated overnight at $37^{\circ} \mathrm{C}\left(5 \% \mathrm{CO}_{2}\right.$ at $98 \%$ humidity) wherein the log phase of their growth curve was attained.

In a master dilution plate (MDP), $4 \mathrm{mg} /$ $\mathrm{mL}$ of extracts were diluted successively to the concentration of $1000 \mu \mathrm{g} / \mathrm{mL}, 500 \mu \mathrm{g} / \mathrm{mL}, 250 \mu \mathrm{g} /$ $\mathrm{mL}$ and $125 \mu \mathrm{g} / \mathrm{mL}$. Ten microliters were retrieved after the MDP and were distributed to the plated cells to get the final concentrations of $100 \mu \mathrm{g} / \mathrm{mL}$, $50 \mu \mathrm{g} / \mathrm{mL}, 25 \mu \mathrm{g} / \mathrm{mL}, 12.5 \mu \mathrm{g} / \mathrm{mL}$, and $6.25 \mu \mathrm{g} /$ $\mathrm{mL}$. Eight two-fold dilutions of the sample were used as treatments starting from $100 \mu \mathrm{g} / \mathrm{mL}$ down to $0.78125 \mu \mathrm{g} / \mathrm{mL}$. Concentrations were determined in line with the study of Dapat, et al. (2013) and Tantengco, et al. (2015).

The positive control was eight three-fold dilutions of Doxorubicin (Sigma, St. Louis, USA), an anthracycline antibiotic with antineoplastic activity used for cancer chemotherapy. A solvent for the extracts known as DMSO (Sigma) serves 
as the negative control. Following incubation, cells were treated with each extract dilution. The treated cells were again incubated for $72 \mathrm{~h}$ at $37^{\circ} \mathrm{C}$ and $5 \%$ $\mathrm{CO}_{2}$.

Following the incubation period, the media was removed and $20 \mu \mathrm{L}$ of MTT dye (Sigma Aldrich) at $5 \mathrm{mg} / \mathrm{mL}$ phosphate-buffered saline (Roche, Germany) was dispensed to all the wells. There was another incubation period for the cells for $4 \mathrm{~h}$ at $37^{\circ} \mathrm{C}\left(5 \% \mathrm{CO}_{2}\right)$. After incubation, 150 $\mu \mathrm{L}$ of DMSO was added to every well. A Ledetect reader was used at $570 \mathrm{~nm}$ to read the absorbance. A linear regression of the absorbance graph against concentration was used to compute the halfmaximal inhibitory concentration $\left(\mathrm{IC}_{50}\right)$, which is the concentration needed to kill $50 \%$ of the cell population.

Assay optimization was done by subtracting the MTT absorbance of cancer cells treated with $A$. bunius extract and the plant extract's absorbance to eliminate possible color interference at $570 \mathrm{~nm}$.

\section{Statistical Analysis}

In determining the phytochemical substituents of A. bunius leaves crude extract, the results were presented as + (positive) and (negative), depending on which substituent was present in the extract.
For DPPH assay, results were presented as frequencies and mean $\pm \mathrm{SD}$ of triplicates from three independent experiments. GraphPad Prism 8 was then used to calculate for the $\mathrm{IC}_{50}$ of DPPH and MTT cytotoxicity assay. The $\mathrm{IC}_{50}$ value was calculated to determine the sample concentration required to inhibit $50 \%$ of the free radicals. The computed two $\mathrm{IC}_{50}$ per assay were compared using independent samples t-test. Specifically, t-test was used to determine if there is a significant difference in the $\mathrm{IC}_{50}$ of (1) A. bunius leaves extract and L- Ascorbic acid, (2) A. bunius leaves extract and Doxorubicin on HCT-116 human colorectal and, (3) A. bunius leaves extract and Doxorubicin on A549 human lung adenocarcinoma cancer cell line. Other data needed was assessed in the software SPSS 23.0, and differences with $p<0.05$ was considered significant.

\section{RESULTS}

\section{Phytochemical Screening}

Table 1 below showed the different phytochemical compounds present in A. bunius leaves extract. The result of analyses revealed reducing sugars, carbohydrates, unsaturated lactones, saponins, diterpenes, phenolics, tannins, and flavonoids.

Table 1. Qualitative Phytochemical Analysis of A. bunius Leaves Extract.

\begin{tabular}{|c|c|c|c|c|c|}
\hline Test for Constituents & $\begin{array}{l}\text { Constituents } \\
\text { Detected }\end{array}$ & Results & Test for Constituents & $\begin{array}{c}\text { Constituents } \\
\text { Detected }\end{array}$ & Results \\
\hline Detection of Alkaloids & & & Detection of Phytosterols & & \\
\hline - Mayer's test & Alkaloids & - & - Cupric acetate test & Diterpenes & + \\
\hline - Dragendorff's test & Alkaloids & - & - Salkowski’s test & Triterpenes & - \\
\hline - Hager's test & Alkaloids & - & - Liberman Burchard test & Phytosterols & - \\
\hline - Wagner's test & Alkaloids & - & & & \\
\hline Detection of Carbohydrates & & & Detection of Phenolic Compounds & & \\
\hline - Molisch's test & Carbohydrates & + & - Ferric Chloride test & Phenolics & + \\
\hline - Fehling's test & Reducing sugars & + & - Gelatin test & Tannins & + \\
\hline \multicolumn{6}{|l|}{ Detection of Glycosides } \\
\hline \multirow[t]{2}{*}{ - Modified Borntrager's test } & Anthraquinone & - & Detection of Flavonoids & & \\
\hline & glycosides & & - Alkaline Reagent test & Flavonoids & + \\
\hline - Kedde test & $\begin{array}{l}\text { Unsaturated } \\
\text { lactones }\end{array}$ & + & - Lead Acetate test & Flavonoids & + \\
\hline Detection of Saponins & & & Detection of Proteins & & \\
\hline - Froth Test & Saponins & + & - Xanthoproteic test & Proteins & - \\
\hline - Foam test & Saponins & + & & & \\
\hline
\end{tabular}




\section{Diphenylpicrylhydrazyl (DPPH) Assay}

Figure 1 indicated that the $\mathrm{IC}_{50}$ of the A. bunius leaves extract was increased in a concentration-dependent manner. Among the four concentrations of $A$. bunius crude extract, 5000 $\mu \mathrm{g} / \mathrm{mL}$ showed the highest free radical scavenging activity $(67.29 \pm 0.56)$.

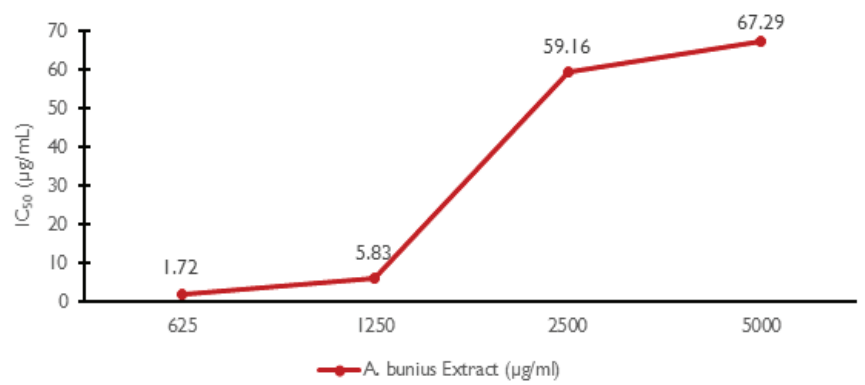

Figure 1. Free radical scavenging activity of the four concentrations of $A$. bunius leaves extract on DPPH Assay.

Figure 2, on the other hand, showed the comparison between the free radical scavenging activity of L-Ascorbic acid and A. bunius leaves extract. Independent samples t-test revealed that $A$. bunius leaves extract $(\mathrm{M}=3.27, \mathrm{SD}=0.00208)$ was significantly different $(p<0.001)$ from L-ascorbic acid $(\mathrm{M}=2.43, \mathrm{SD}=0.00493)$. This indicated that A. bunius leaves extract antioxidant activity was active but lower than L-ascorbic acid.

Figure 3 showed the difference between the $\mathrm{IC}_{50}$ of $A$. bunius leaves extract and Doxorubicin against HCT-116 human colorectal cancer cells. Independent samples t-test revealed that $A$. bunius leaves extract $(\mathrm{M}=0.452, \mathrm{SD}=0.15)$ was

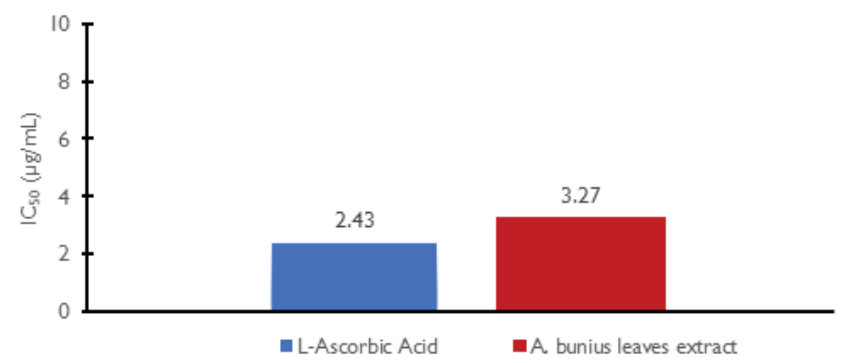

Figure 2. Log IC $C_{50}$ values of L-Ascorbic acid and A. bunius leaves extract on DPPH Assay. significantly different $(p<0.05)$ from Doxorubicin $(\mathrm{M}=0.0567, \mathrm{SD}=0.015)$. This result indicated that A. bunius leaves extract has cytotoxic activity against HCT-116 human colorectal cancer cells but lower than Doxorubicin.

Figure 4 showed the difference between the $\mathrm{IC}_{50}$ of $A$. bunius leaves extract and Doxorubicin against the A549 lung adenocarcinoma cell line. Independent samples t-test showed that $A$. bunius leaves extract $(\mathrm{M}=1.75, \mathrm{SD}=1.12)$ was not

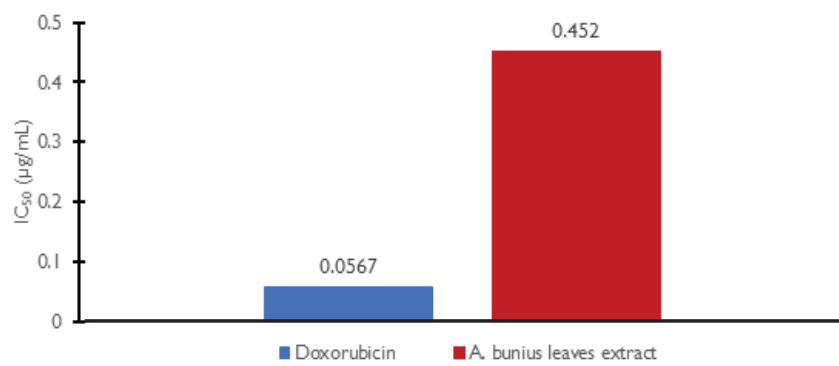

Figure 3. $\mathrm{IC}_{50}$ values of Doxorubicin and $A$. bunius leaves extract against HCT-116 human colorectal cancer cell line.

significantly different $(p>0.05)$ from Doxorubicin $(\mathrm{M}=0.14, \mathrm{SD}=0.05)$. This result indicated that $A$. bunius leaves extract has a similar dose-dependent cytotoxic activity of Doxorubicin against A549 human lung cancer cells.

\section{DISCUSSION}

Qualitative phytochemical analysis of $A$. bunius leaves revealed the presence of unsaturated lactones, flavonoids, phenolics, diterpenes, saponins, and tannins. These exhibited both

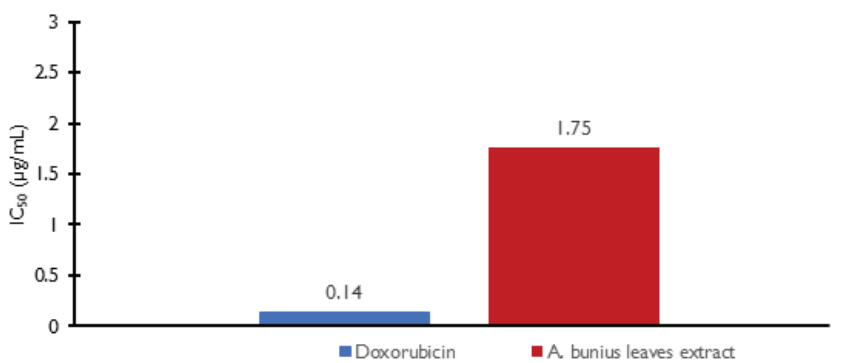

Figure 4. IC $C_{50}$ values of Doxorubicin and $A$. bunius leaves extract against A549 lung adenocarcinoma cell line. 
antioxidant and anticancer properties reported in several studies. In a study by Tantawy, et al. (2015), on the hypoglycemic property evaluation of $A$. bunius leaves, phytochemicals identified were the same as the present study. Another study by Jorjong, et al. (2015), using the fruit sample of $A$. bunius, has demonstrated flavonoids and phenolics determined to be present in A. bunius leaves.

The antioxidant activity of the extract was demonstrated through the DPPH assay. This test was used because of its characteristics and availability. According to Škrovánková, et al. (2012), the DPPH test is commonly used because of the short time of analysis, the free radical's stability, and measurable reaction. DPPH has been widely adopted in measuring the free radical scavenging activity of antioxidants. This assay is solely based on the reduction of an alcoholic DPPH solution using a hydrogen-donating antioxidant (Fatiha and Abdelkader, 2019).

The $\mathrm{IC}_{50}$ value indicated that $A$. bunius leaves extract has less potent radical scavenging activity than L-ascorbic acid; therefore, to yield similar effects with L-ascorbic acid, a higher dose is needed. Free radical scavenging activity either prevents the generation of reactive oxygen species or eliminates them before they damage the cell's vital components (Riaz, et al., 2012). According to a study from the US National Cancer Institute, antioxidants prevent damage to cells by donating electrons to stabilize the free radicals, heal damaged cells, and delay or prevent cancer (Olsen and Ware, 2018).

In a study by Islam, et al. (2018), methanolic leaves extract of $A$. bunius possessed excellent antioxidant activity similar to that of the ethanolic leaves extract of $A$. bunius used in this study. Several studies revealed phytochemical compounds that exhibit free radical scavenging activity, which was present in A. bunius leaves extract. Such compounds include unsaturated lactones, saponins, diterpenes, phenolics, and tannins (Yang, et al., 2016; Chen, et al., 2014; Perez and Ahuatzi, 2015; Daglia, 2012).
Literature has revealed the antioxidant property of unsaturated lactones and flavonoids through inhibiting nitric oxide (Yang, et al., 2016). Phenolics are widely known to have protective effects as antioxidants by lowering free radicals present in the body. In recent years, evidence has shown that small amounts of phenolics have modulatory effects on selective intracellular signaling pathways critical for cellular functions such as proliferation and apoptosis (Ozcan, et al., 2014). Diterpenes, on the other hand, are found to be effective antioxidant by inhibiting lipid peroxidation and lipoxygenase (Perez and Ahuatzi, 2015).

The MTT assay of A. bunius leaves extract revealed activity against HCT-116 human colorectal and A549 lung adenocarcinoma cancer cell lines. The cytotoxic activity of A. bunius is also supported by the previous studies against brine shrimp (Zaman, et al., 2018) and MCF-7 breast cancer cell line (Subarnas, et al., 2012).

An extract that exhibits in vitro cytotoxicity against cancer cells can be used as a possible drug source if it reveals an $\mathrm{IC}_{50}$ value not greater than 30 $\mu \mathrm{g} / \mathrm{mL}$ (Suffness and Pezzuto, 2009). In this study, the $\mathrm{IC}_{50}$ value of the A. bunius leaves extract is lower than $30 \mathrm{ug} / \mathrm{mL}$ in both cancer cell lines. Therefore, these findings support the notion that A. bunius extract can be a potential source of antineoplastic compounds.

The cytotoxic activity may be attributed to the phytochemical compounds, namely, saponins, diterpenes, tannic acid, polyphenols, and flavonoids. Flavonoids found in different plant sources showed activity against lung cancer cells (Al-Taweel, et al., 2015). Antitumor properties of flavonoids include decreasing mitochondrial potential, overexpressing Fas and FADD ligands, and promoting DNA fragmentation (Abotaleb, et al., 2019). A study done by Gong, et al. (2014) revealed a positive inhibition of nicotine-induced lung cancer cells by flavonoid compounds through interference with genes (MMPs) that regulate the initiation of metastasis. Reduction in the risk of 
tumor formation is associated with flavonoids' dietary intake (Donato and Romagnolo, 2012).

Based on this study's phytochemical determination, A. bunius contains saponins that were found to possess antitumor effects on many cancer cells (Shuli Man, 2010). As studied by He, et al. (2014), it effectively inhibits the invasion and metastases of the A549 lung cancer cell line by mechanisms similar to flavonoids inhibiting matrix metallopeptidase (MMP) genes. Studies showed that diterpenes exhibit antitumor property and have been proven to possess moderate or strong antiproliferative effects on various human cancer cell lines, including colon carcinomas (Vasas, et al., 2014). Polyphenols are thoroughly studied, and it has been recognized as a chemopreventive agent against cancer such as colorectal cancer (Araújo, et al., 2011). Tannic acid is reported to be effective against colon carcinogenesis by ameliorating inflammatory damage and oxidative stress (Oday and Hamiza, 2012).

A breakthrough in pharmacologic medicine is the discovery of a complex diterpene marketed as Paclitaxel. Paclitaxel is an anticancer agent that inhibits the metaphase-anaphase transition in cancer cells by suppressing the spindle microtubule dynamics leading to mitosis inhibition inducing apoptosis (Khanna, et al., 2015). Saponins can induce apoptosis and inhibit cancer cell growth through G1 cell cycle arrest (Yu, et al., 2015). Lastly, tannins are found to cause cell cycle arrest in S phase and promotion of apoptosis (intrinsic pathway) through BCL-XL downregulation accompanied by the mitochondrial release of cytochrome $\mathrm{C}$ into the cytoplasm leading to activation of caspase 9 (initiator) and caspase 3 (effector) (Yildirim and Kutlu, 2015).

The study was limited to the qualitative determination of the phytochemicals, colorimetric antioxidant assay, and in vitro cytotoxic assay. Further studies to quantitatively evaluate and isolate A. bunius leaves active components, determination of the total antioxidant capacity, evaluation of the mechanism of cytotoxicity, and tumor selectivity determination are recommended.

To our knowledge, this is the pioneer study to report about the biologic activity of the A. bunius against the mentioned carcinoma cells. The findings of this study were geared towards its contribution to drug discovery and development, responding to the challenge of drug innovations on cancer chemotherapy and chemoprevention. This study supports promoting and exploring indigenous plants, particularly in the Philippines, on unraveling the potentials found within the said plants.

\section{CONCLUSION}

A. bunius leaves extract is a rich source of a variety of phytochemicals. The extract showed significant free radical inhibition activity. Also, it exhibited cytotoxic activity against lung and colorectal cancer. Hence, A. bunius leaves have the potential to be a source of natural antioxidant and antineoplastic compounds. This study recommends further isolation and evaluation of the active compounds for chemotherapeutic purposes.

\section{CONFLICT OF INTEREST}

All authors declare no conflict of interest.

\section{FUNDING}

This research did not receive any specific grant from funding agencies in the public, commercial, or not-for-profit sectors.

\section{ACKNOWLEDGMENT}

The researchers would like to express their appreciation to Prof. Jonathan Barcelo, Prof. Gabriel Glenn Ochoa, Sir Kevin Christian Olarte, and $\mathrm{Ma}$ 'am Briege Martin for sharing their expertise and guidance. 


\section{REFERENCES}

Abotaleb, M., Samuel, S., Varghese, E., Varghese, S., Kubatka, P., Liskova, A. and Busselberg, D., 2019, Flavonoids in cancer and apoptosis, Cancers (Basel), 11(1), 28.

Al-Taweel, A.M., Perveen, S., Fawzy, G.A., Ibrahim, G.A., Khan, A. and Mehmood, R., 2015, Cytotoxicity assessment of six different extracts of Abelia triflora leaves on A-549 human lung adenocarcinoma cells, Asian Pac. J. Cancer Prev., 16, 4641-4645.

Araújo, J.R., Goncalves, P. and Martel, F., 2011, Chemopreventive effect of dietary polyphenols in colorectal cancer cell lines, Nut. Res., 77-87.

Ballesteros, L.F., Teixeira, J.A. and Mussatto, S.I., 2014, Selection of the solvent and extraction conditions for maximum recovery of antioxidant phenolic compounds from coffee silver skin, Food Bioprocess Technol., 7, 1322-1332.

Barcelo, R.C., 2015, Phytochemical Screening and Antioxidant Activity of Edible Wild Fruits in Benguet, Cordillera Administrative Region, Philippines, Electronic Journal of Biology, 11(3), 80-89.

Bray, F., Ferlay, J., Soerjomataram, I., Siegel, R.L., Torre, L.A. and Jemal, A., 2020, Global cancer statistics 2018: GLOBOCAN estimates of incidence and mortality worldwide for 36 cancers in 185 countries, CA Cancer J. Clin., 70(4), 313.

Butkhup, L. and Samappito, S., 2008, An analysis on flavonoids contents in mao luang fruits of fifteen cultivars (Antidesma bunius), grown in northeast Thailand, Pak. J. Biol. Sci., 11(7), 996-1002.

Calin, G.A., Trapasso, F., Shimizu, M., Dumitru, C.D., Yendamuri, S., Godwin, A.K., et al., 2005, Familial cancer associated with a polymorphism in ARLTS1, N Engl J Med, 352(16), 1667-1676.

Chen, Y., Miao, Y., Huang, L., Li, J., Sun, H., Zhao, Y., Yang, J. and Zhou, W., 2014, Antioxidant activities of saponins extracted from Radix trichosanthis: an in vivo and in vitro evaluation, BMC Complement Altern. Med., 5(14), 86.

Clarke, G., Ting, K.N., Wiart, C. and Fry, J., 2012, High correlation of 2,2-diphenyl-1picrylhydrazyl (DPPH) radical scavenging, ferric reducing activity potential and total Phenolics content indicates redundancy in use of all three assays to screen for antioxidant activity of extracts of plants from the Malaysian rain forest, Antioxidants, 2(1), 1-10.

Daglia, M., 2012, Polyphenols as antimicrobial agents, Curr. Opin. Biotechnol., 23(2), 174-81.

Dapat, E., Jacinto, S. and Efferth, T., 2013, A phenolic ester from Aglaia loheri leaves reveals cytotoxicity towards sensitive and multidrugresistant cancer cells, BMC Complement. Altern. Med., 13, 286.

Do, Q.D., Angkawijaya, A.E., Tran-Nguyen, P.L., Huynh, L.H., Soetaredjo, F.E., Ismadji, S., et al, 2014, Effect of extraction solvent for total phenol content, total flavonoid content \& antioxidant activity of Limnophilia aromatica, J. Food Drug Anal., 22(3), 296-302.

Donato, F. and Romagnolo, O.I., 2012, Flavonoids and cancer prevention: a review of the evidence, $\mathrm{J}$. Nutr. Gerontol. Geriatr., 31(3), 206-38.

El-Tantawy, W., Soliman, N., El-naggar, D. and Shafei, A., 2015, Investigation of antidiabetic action of Antidesma buniusextract in type 1 diabetes, Archives of Physiology and Biochemistry, 121(3), 116-122.

Fatiha, M. and Abdelkader, T., 2019, Study of antioxidant activity of pyrimidinium betaines by DPPH radical scavenging method, Journal of Analytical \& Pharmaceutical Research, 8(2), 33-36.

Gong, W., Wu, J., Liu, B., Zhang, H., Cao, Y., Sun, J., and Dong, J., 2014, Flavonoid components in Scutellaria baicalensis inhibit nicotine-induced proliferation, metastasis and lung cancerassociated inflammation in vitro, Int. J. Oncol., 44(5), 1561-70.

Guevara, B.Q., 2005, A guidebook to plant screening: 
phytochemical and biological, Manila: UST Publishing House, 156.

Hamiza, O.O., Rehman, M.U., Tahir, M., Khan, R., Khan, A.Q., Lateef, A., et al., 2012, Amelioration of 1,2 dimethylhydrazine (DMH) induced colon oxidative stress, inflammation and tumor promotion response by tannic acid in wistar rats, Asian Pac. J. Cancer Prev., 13(9), 4393-4402.

He, H., Zheng, L., Sun, Y., Zhang, G. and Yue, Z.. 2014, Steroidal saponins from Paris polyphylla suppress adhesion, migration and unvasion of human lung cancer A549 cells via downregulating MMP-2 and MMP-9, Asian Pac. J. Cancer Prev., 15(24), 10911-10916.

Islam, S., Koly, S., Zaman, S., Sukorno, F., Ahammed, S., Munira, S. and Hridoy, R., 2018, Estimation of phytochemical, antioxidant screening profile and thrombolytic activities of methanolic extract of Antidesma bunius L. leaf., Int. J. Hortic. Sci. Technol., 6, 358-363.

Jorjong, S., Butkhup, L. and Samappito, S., 2015. Phytochemicals and antioxidant capacities of Mao-Luang (Antidesma bunius L.) cultivars from Northeastern Thailand, Food Chemistry, 181, 248-255.

Juan, M.E., Muaña, C.G., Comiso, J.L., Leon, R.M., Guinto, C.C., Honorio, T.A., Ibut, M.A. and Zanoria, S.A., 2014, Antiangiogenic property of bignay (Antidesma bunius) ethanolic leaf extraction in duck (Anas luzonica) embryo using chorioallantoic membrane (CAM) assay, Root Gatherers Journal, 7(1), 1-16.

Kassem, M.E.S., Hashim, A.N. and Hassanein, HM, 2013, Bioactivity of Antidesma bunius leaves (Euphorbiaceae) and their major phenolic constituents, Eur. Sci. J., 9(18), 217-228.

Khanna, C., Rosenberg, M. and Vail, D.M., 2015, A Review of Paclitaxel and Novel Formulations including Those Suitable for Use in Dogs, JVIM, 29(4), 1006-1012.

Man, S., Gao, W., Zhang, Y., Huang, L. and Liu, C., 2010, Chemical study and medical application of saponins as anticancer agents, Fitoterapia, 81(7), 703-714.

Micor, J.R.L., Deocaris, C.C. and Mojica, E.E., 2005, Biological activity of bignay [Antidesma bunius (L.) Spreng] crude extract in Artemia salina, J. Med. Sci., 5(3), 195-198.

Mohan, A., Sethuraman, S., Narayanan, S. and Krishnan, U.M., 2013, Combinations of plant polyphenols \& anticancer molecules: a novel treatment strategy for cancer chemotherapy, Anticancer Agents Med. Chem., 13(2), 281-95.

Mondal, S., Ghosh, M.K., Bandyopadhyay, S., Mukhopadhyay, S., Mandal, C. and Roy, S., 2012, Natural Products: Promising resources for cancer drug discovery, Anticancer Agents Med. Chem., 12(1), 49-75.

Mosmann, T., 1983, Rapid colorimetric assay for cellular growth and survival: application to proliferation and cytotoxicity assays, J. Immunol. Methods, 65, 55-63.

Olsen, N. and Ware, M., 2018, Antioxidants: health benefits and nutritional information. Medical News Today, Website from: https://www. medicalnewstoday.com/articles/301506.php. Accessed on April 12, 2019.

Ozcan, T., Akpinar-Bayizit, A., Yilmaz-Ersan, S. and Delikanli, B., 2014, Phenolics in human health, IJCEA, 5(5), 393-396.

Perez, R. and Ahuatzi, D., 2015, Investigating antioxidant properties of the diterpenes from seeds of Phalariscanariensis, J. Nutr. Food Sci., 5(4), 376.

Reid, W., Mooney, H., Cropper, A. and Capistrano, D., 2005, Ecosystems and Human Wellbeing: Synthesis. Website, https://www. millenniumassessment.org/documents / document.356.aspx.pdf; accessed on July 12 2020.

Riaz, T., Abbasi, M., Rehman, A., Shahzadi, T., Ajaib, M. , and Khan, K. , 2012, Phytochemical screening, free radical scavenging, antioxidant activity and phenolic content of Dodonaea viscosa Jacq., J. Serb. Chem. Soc., 77(4), 423-435. 
Siegel, R.L., Miller, K.D. and Jemal, A., 2019, Cancer statistics, CA Cancer J Clin., 69(1), 7-34.

Škrovánková, S., Mišurcová, L. and Machů, L., 2012. Antioxidant Activity and Protecting Health Effects of Common Medicinal Plants, Advances in Food and Nutrition Research, 67, 75-139.

Subarnas, A., Diantini, A., Abdulah, R., Zuhrotun, A. Yamazaki Kobayashi, C., Nakazawa, M. and Koyama, H., 2012, Antiproliferative activity of primates-consumed plants against MCF-7 human breast cancer cell lines, E3 Journal of Medical Research, 1, 38-43.

Suffness, M. and Pezzuto, J.M., 2009, Assay related to cancer drug discovery. In: Hostettman K, editor. Methods in plant biochemistry: assay for bioactivity. London: Academic Press 71-133.

Tantengco, O.A., Limbo, C., Montaño, M.N. and Jacinto, S., 2015, Cytotoxic activity of crude extract and fractions from Sargassum siliquosum (JG Agardh) and other seaweeds against selected human cancer cell lines, International Journal of Biosciences, 7(2), 207-215.

Vasas, A. and Hohmann, J., 2014, Euphorbia diterpenes: isolation, structure, biological activity and synthesis, Chem. Rev., 114(17), 8579-8612.

Yang, B., Kong, L., Wang, X., Zhang, Y., Li, R., Yang, M., and Luo, J., 2016, Nitric oxide inhibitory activity and absolute configurations of arylalkenyl a, B-unsaturated $\delta / \gamma$-lactones from Cryptocaryaconcinna, J. Nat. Prod., 79(1), 196203.

Yildirim, I. and Kutlu, 2015, Anticancer Agents: Saponin and Tannin, International Journal of Biological Chemistry, 9(6), 332-340.

Yu, Z., Zhang, T., Zhou, F., Xiao X., Ding, X., He, H., et al., 2015, Anticancer activity of saponins from Allium chinense against the B16 melanoma and 4T1 breast carcinoma cell, Evid. Based Complement Alternat. Med., 2015(725023), 1-12.

Zaman, S., Islam, M., Koly, S., Faisal, T. and Rakib, K., 2018. Evaluation of Cytotoxicity and Antibacterial Activities of Methanolic Extract of Antidesma bunius (Linn.) (Family Euphorbiaceae) Leaf, Journal of Advances in Medical and Pharmaceutical Sciences, 16(2), 1-7.

Zhou, Y., Wan, G., Spizzo, R., Ivan, C., Mathur, R., $\mathrm{Hu}, \mathrm{X}$. , et al., 2014, miR-203 induces oxaliplatin resistance in colorectal cancer cells by negatively regulating ATM kinase, Mol. Oncol., 8(1), 83-92.

Zulkipli, I., David, S., Rajabalaya, R. and Idris, A., 2015, Medicinal plants: a potential source of compounds for targeting cell division, Drug Target Insights, 9, 9-19. 